\title{
Effect of Earthquake and Progressive Collapse Potential of RC Frame Structure: with and without the involvement of infill wall stiffness's
}

\author{
Akshay M. Divate \\ Department of Civil Engineering (P.G. Student Structural Engineering) \\ KLS Gogte Institute of Technology, Belagavi, Karnataka, India \\ Raghunath D. Deshpande \\ Department of Civil Engineering (Assistant Professor) \\ KLS Gogte Institute of Technology, Belagavi, Karnataka, India \\ Rajendra J. Thakai \\ Department of Civil Engineering (Assistant Professor) \\ KLS Gogte Institute of Technology, Belagavi, Karnataka, India
}

\begin{abstract}
Those two significant reasons that participate in collapse of reinforced concrete frames are natural hazards (earthquake, floods, fires, tornadoes and hurricanes) or manmade hazards (impact and blast), that may be designated as seismic collapse and structural progressive collapse. The majority of investigations manage to deal with one of these collapse patterns, in-spite of the fact that both of them should be taken into account for structural analysis and design. To inquire into structural progressive and seismic collapse capabilities, nonlinear static analysis is carried out to a reinforced concrete frame structure with and without the contribution of masonry-infill walls thus for modeling of nonlinear hinges in beams and columns ASCE 41 is used. The progressive collapse and seismic collapse provide non-identical deformation and force demands for the structural columns and beams.
\end{abstract}

Keywords - progressive collapse, seismic collapse, masonry-infill frame, nonlinear static analysis and design

\section{INTRODUCTION}

Progressive collapse in a building happens when real structural load carrying parts (like columns) suddenly breakdown due to unintentional loads for example, impact alternately sway (manmade hazards) or earthquakes, hurricanes, tornadoes, floods, what's more burst (natural hazards). Continuously recognized concerning illustration dubious should happen done in past, these remarkable occasions might presently be recognized over different scenarios, hosting an set likelihood from claiming event. Thus obviation of progressive collapse appears to be a consequential issue in the development for a few configuration structural codes. The current codes viewing outline guidelines highlight general need for keeping progressive collapse, in light of giving addition structural ductility, integrity and excess with by implication invalidate those danger for disproportionate collapse.

Consequence for progressive collapse of buildings came under consideration for structural designers starting with the partial collapse of 22 story Ronan Point Tower Apartment - London (May 1968), as there was a gas explosion occurred on the 18th floor that energetically took out the exterior load bearing panels of the kitchen near the outer most bay of the building. As a result there was loss of support at that particular story (i.e., 18th floor), encouraging the above floors to collapse. Thus, the potential of this collapsing floors caused impact load on lower stories and set-up a progressive collapse. The complete outer-side corner of the building collapsed from top to bottom. Also, with rapid increase in continuous terrorist activities and climax of September 2001 event, that was the collapse of World Trade Center (WTC) towers in New York, an interest in this topic has been increased. Many regime and private ascendant entities worked on refining design guidelines for progressive collapse-resistant structures [13].

Thus from last three decades, the United Kingdom (U.K.). Building Regulations have demanded the necessity to avoid disproportionate collapse, which were developed in fulfillment, with Ronan Point event and remained unaltered till today. Euro-code sets separate applied regulations for those buildings, that must be checked for progressive 
collapse. It may withal be utilized as guidance for the tenacity of actions to be taken into account during: structural alterations, reconstruction, partial or full demolition of structure [13].

Also in the United States there are various rules accommodated for administration documents that gatherings give plan directions for progressive collapse imperviousness from claiming structures. Such documents were given eventually by the U.S. General Service Administration (GSA), Department of Defense (DoD) and Interagency Security Committee. These design documents were issued for examining the guidelines for progressive collapse assessment for building structures based on GSA guidelines that takes into consideration for a developed possible series of failure in the columns of R.C.C structural frame alternately structures with thick slabs, hence from the chain of events that have been studied by many researchers, have ventured to appraise the effect of progressive collapse resistance on dissimilar types of structures.

The present study makes an effort to understand the effect of seismically designed R.C frame structure located on medium type of soil for seismic zone factor of 0.24 (i.e., for zone IV) in prevention of progressive collapse of building. The analysis has been carried out using commercially available structural analysis software ETABS Version 9, that implements plastic hinge properties described in FEMA- 356.

\section{OBJECTIVES -}

1) Allow for limited localized damage of members and investigation of potential failure mechanisms, measuring vertical displacement of the joint above the column removed and study the variation for bending moment and axial force.

2) Investigate the progressive collapse behavior of seismically designed concrete structure, that has suffered loss of critical members as a result of an extreme loading scenario.

3) To clarify, impact from claiming non-structural parts on the structural reaction for the progressive and seismic collapse possibility of a R.C frame building, considering nonlinear static analysis procedure.

\section{MODELING OF BRICK INFILL}

\section{Equivalent diagonal strut method-}

To evaluate the increased stiffness of structure through infill walls material and geometric properties of equivalent diagonal strut are necessary for the frame analysis. Calculated equivalent width of the strut and its thickness is similar to those material and geometric properties of infill walls. Stafford Smith established equation for length of contact between wall and column $\left(\alpha_{h}\right)$ and length of contact between wall and beam $\left(\alpha_{L}\right)$ in 1966. The equations below are used to determine $\alpha_{\mathrm{h}}$ and $\alpha_{\mathrm{L}}$, those depend on relative stiffness and geometric properties of infill.

$$
\alpha_{h}=\frac{\pi}{2} \sqrt[4]{\frac{4 E_{f} I_{c} h}{E_{m} t \sin 2 \theta}} \quad \alpha_{L}=\pi \sqrt[4]{\frac{4 E_{f} I_{b} L}{E_{g} t \sin 2 \theta}}
$$

Where, $\mathrm{E}_{\mathrm{m}}=$ Elastic modulus of the masonry wall and

$\mathrm{E}_{\mathrm{f}}=$ Elastic modulus of frame respectively.

$\mathrm{t}, \mathrm{h}, \mathrm{L}=$ Thickness, height, and length of the infill wall, respectively.

$I_{c}, I_{b}=$ moment of inertia of the column and the beam of the frame, respectively .

$$
\Theta=\tan -1 \quad(\mathrm{~h} / \mathrm{L})
$$

Hendry (1998) assumed that strut is subjected to uniform compressive stress and proposed the following equation to determine the equivalent width of strut also called as effective width of strut,

$$
w=\frac{1}{2} \sqrt{\alpha_{h}^{2}+\alpha_{L}^{2}}
$$

$\alpha_{\mathrm{h}}=$ Contact length between the wall and column.

$\alpha_{\mathrm{L}}=$ Contact length between wall and beam.

In the present study width of strut is calculated as per the equivalent diagonal strut as given by Stafford Smith and Hendry (1963). 


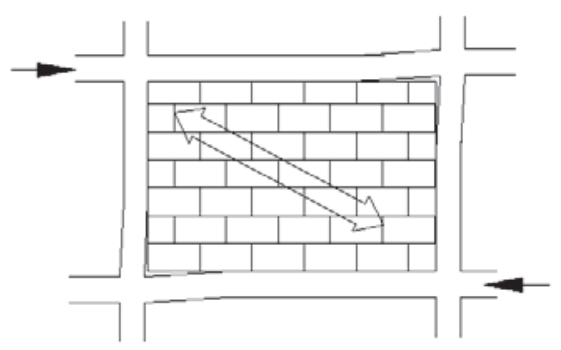

Figure 1. Equivalent diagonal strut

Table -1 Load Combinations

\begin{tabular}{|c|l|c|c|c|}
\hline Sl. No. & \multicolumn{1}{|c|}{ Load Combinations } & DL & LL & EQ \\
\hline 1 & $1.5 \mathrm{DL}+1.5 \mathrm{LL}$ & 1.5 & 1.5 & - \\
\hline 2 & $1.2\left(\mathrm{DL}+\mathrm{LL}{ }^{*}+\mathrm{EQX}\right)$ & 1.2 & $0.25 / 0.5^{*}$ & +1.2 \\
\hline 3 & $1.2\left(\mathrm{DL}+\mathrm{LL}{ }^{*}-\mathrm{EQX}\right)$ & 1.2 & $0.25 / 0.5^{*}$ & -1.2 \\
\hline 4 & $1.2\left(\mathrm{DL}+\mathrm{LL}^{*}+\mathrm{EQY}\right)$ & 1.2 & $0.25 / 0.5^{*}$ & +1.2 \\
\hline 5 & $1.2\left(\mathrm{DL}+\mathrm{LL}{ }^{*}-\mathrm{EQY}\right)$ & 1.2 & $0.25 / 0.5^{*}$ & -1.2 \\
\hline 6 & $1.5(\mathrm{DL}+\mathrm{EQX})$ & 1.5 & - & +1.5 \\
\hline 7 & $1.5(\mathrm{DL}-\mathrm{EQX})$ & 1.5 & - & -1.5 \\
\hline 8 & $1.5(\mathrm{DL}+\mathrm{EQY})$ & 1.5 & - & +1.5 \\
\hline 9 & $1.5(\mathrm{DL}-\mathrm{EQY})$ & 1.5 & - & -1.5 \\
\hline 10 & $0.9 \mathrm{DL}+1.5 \mathrm{EQX}$ & 0.9 & - & +1.5 \\
\hline 11 & $0.9 \mathrm{DL}-1.5 \mathrm{EQX}$ & 0.9 & - & -1.5 \\
\hline 12 & $0.9 \mathrm{DL}+1.5 \mathrm{EQY}$ & 0.9 & - & +1.5 \\
\hline 13 & $0.9 \mathrm{DL}-1.5 \mathrm{EQY}$ & 0.9 & - & -1.5 \\
\hline 14 & $1.2 \mathrm{DL}+0.5 \mathrm{LL}$ & 1.2 & 0.5 & - \\
\hline 15 & $\Omega \mathrm{N}(1.2 \mathrm{DL}+0.5 \mathrm{LL})$ & 1.2 & 0.5 & - \\
\hline
\end{tabular}

where, $\mathrm{DL}=$ Dead Load

$\mathrm{LL}=$ Live Load

$\mathrm{EQX}=$ Earthquake load along $\mathrm{X}$ - direction

$\mathrm{EQY}=$ Earthquake load along $\mathrm{Y}$ - direction

$\Omega \mathrm{N}=$ Dynamic increase factor for nonlinear static procedure 


\section{ANALYTICAL MODEL}
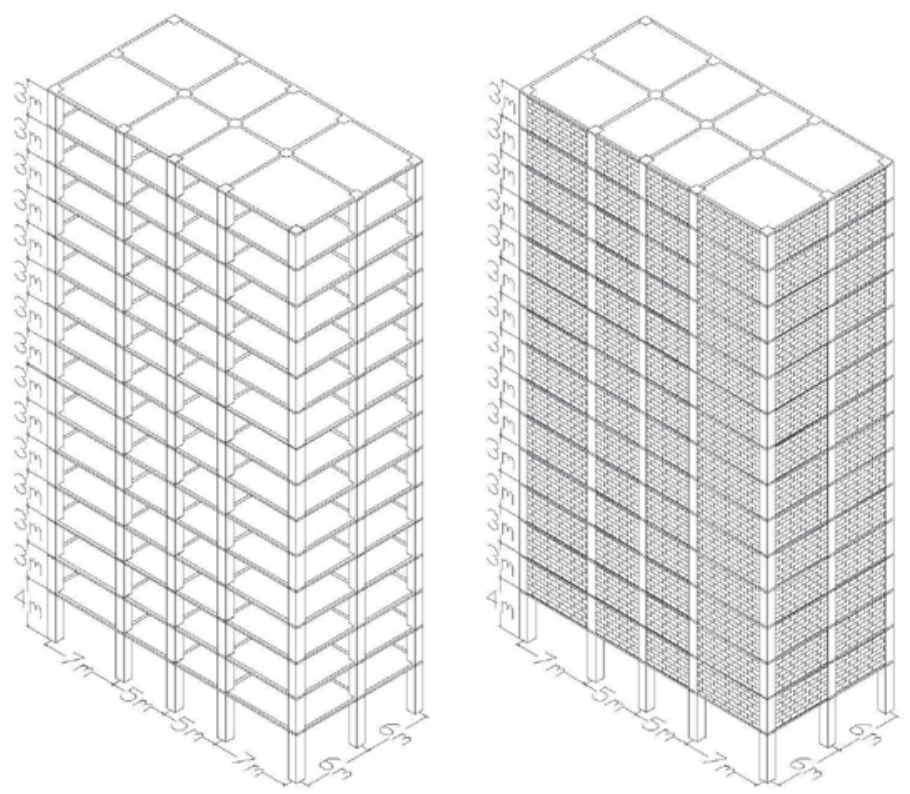

Figure 2. Analytical model showing dimensions.

To study the effect of seismic and progressive collapse resistant's of the structure and to compare a bare frame model with an infill frame model an hypothetical case of 15 storey RC building is been considered. Progressive collapse analysis is based on the GSA guidelines. There is variation in bay size in X-direction and Y-direction, as shown in dimensional plan. The bottom story is taken as $4 \mathrm{~m}$ and height of typical floor as $3 \mathrm{~m}$. Beams and column sections are maintained uniform in size, as illustrated in Figure2. The design is calculated using IS 456:2000 and analysis is done using ETABS Version 9. The behavior of hinges are defined based on FEMA-356 (or ATC- 40) provisions. The materials, sections, loadings used in the model are: Dead Load: Self- weight of structure. Live Load: $1.5 \mathrm{kN} / \mathrm{m}^{2}$ at all floors. Floor finish: $1.0 \mathrm{kN} / \mathrm{m}^{2}$. Water proofing: $2.0 \mathrm{kN} / \mathrm{m}^{2}$. Terrace finish: $1.0 \mathrm{kN} / \mathrm{m}^{2}$. Earthquake load: confirming to IS-1893(Part 1)-2002 using ETABS Program. Storey Height: Typical Floor: 3m, Ground Floor: 4m. Walls: $230 \mathrm{~mm}$ thick brick masonry wall. Columns at floors: $800 \mathrm{~mm} \times 800 \mathrm{~mm}$. Main Beams: $300 \mathrm{~mm} \times 600 \mathrm{~mm}$. Ground Beams: $300 \mathrm{~mm} \times 600 \mathrm{~mm}$. Slab Thickness: $150 \mathrm{~mm}$ thick. Material properties: M30. Yield strength of reinforcing steel (fy) : 415N/mm2. Hinges assigned to the beams are V2 -M3 and those for columns were P-M2-M3. Axial plastic hinges were assigned to the diagonal struts.

\section{RESULTS AND DISCUSSION}

To obtain variation in bending moment, axial force, displacement and shear force, only one column is removed at a time at any story and the structure is analyzed. Hence for this case study the removal of column was selected at base for both the frame as illustrated in Figure3. It is of usual practice to treat the brick infill as a non-structural component and therefore all the lateral load is assumed to be resisted by the frame. A brick infill is highly strung as compared to reinforced concrete frame that surrounds it and fails in an earthquake, previously then the failure of frame. If properly designed, the infill's can lead to increment in overall strength, lateral resistance and can be effective in dissipating energy of the structure, infill's can minimize lateral deflections in frame, thereby decrementing bending moment and the prospect of collapse.

The structure is very less displaced when longer side centre column at base was removed. From all these column removal cases the load gets shifted to the adjacent columns and beams. Thus the displacement of the adjacent columns is to be checked, these value are to be compared with the displacement of the removed column which must be greater than those values obtained on the adjacent members. However, to some extent it can be concluded that longer side centre column removed at base had no significant impact for displacing the structure in case of nonlinear static analysis. But in case of linear static analysis which is based on demand capacity ratio (DCR) the longer side column removed in the frame had dominating effect this is because linear static analysis assumes that the member is with-in the elastic limit and the DCR is used to describe either the member is with-in the elastic limit or not. This event of effect for column removal case had similar impact for both the models. Infilled frames are less deformable then otherwise compared to bare frame structure. 

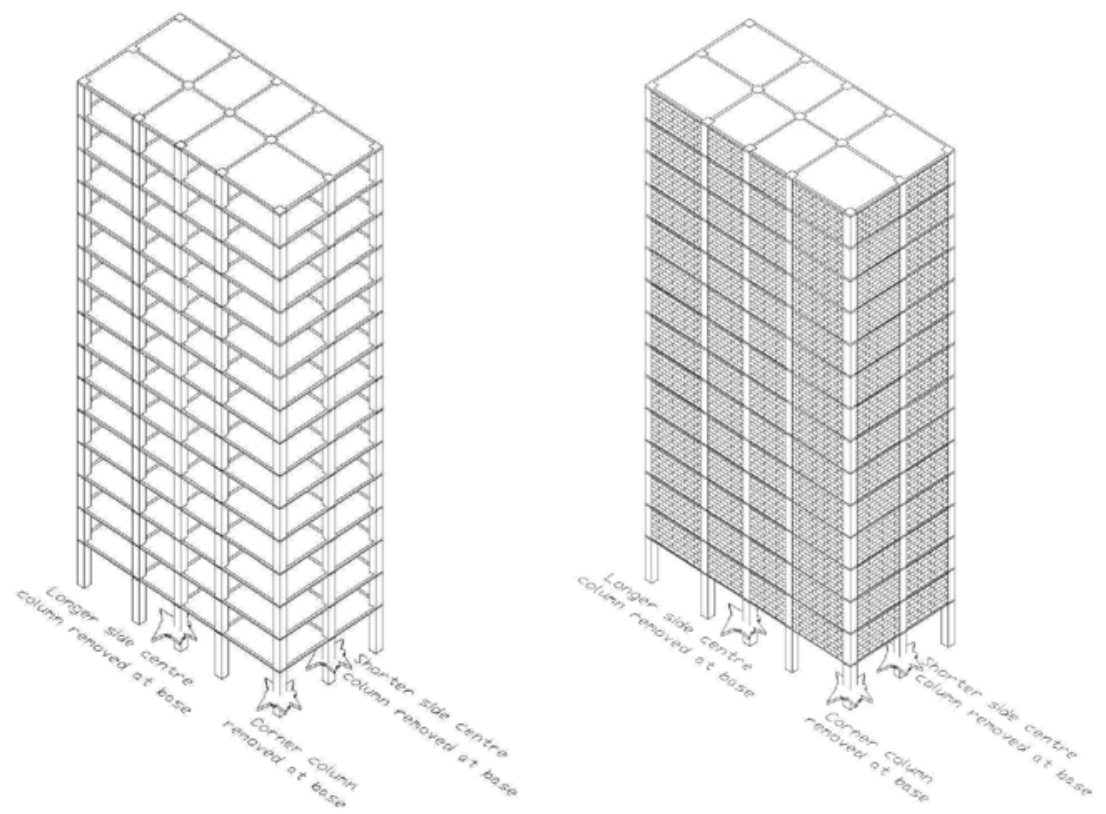

Figure 3. Three cases of column removal for a bare frame and infilled frame structure.

A. Variation in bending moment and axial force for three cases of column removed at base for a bare frame and a frame with masonry-infill structure. -
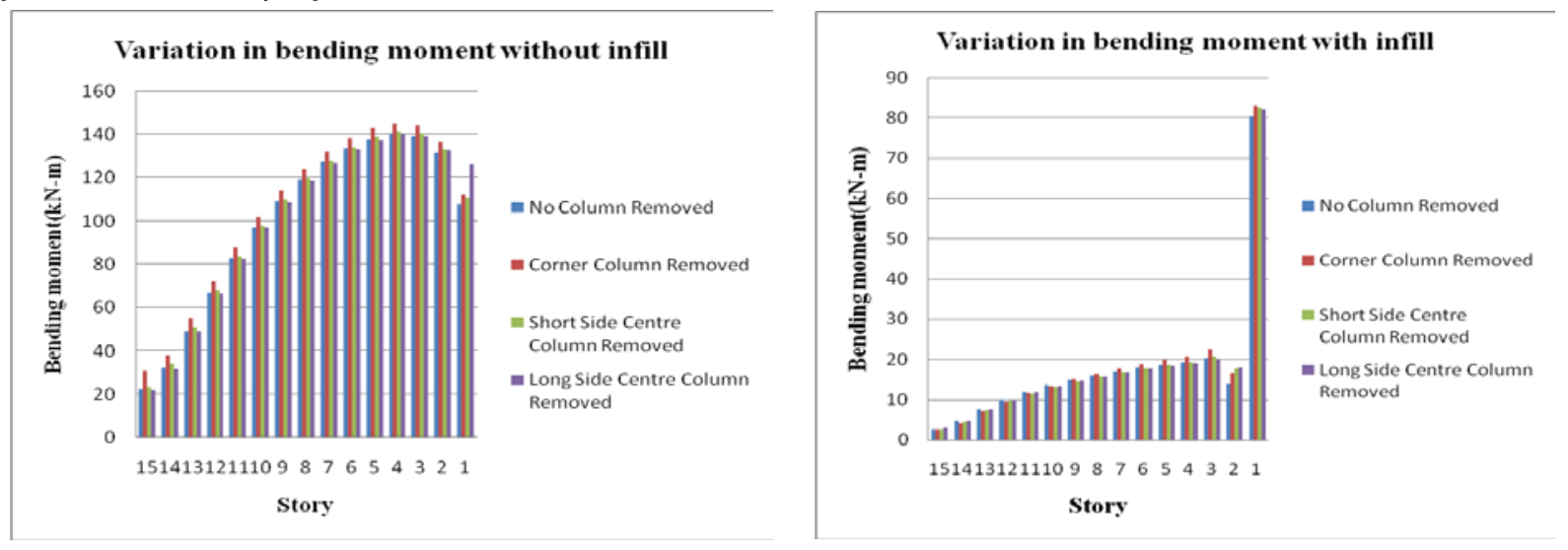

Figure 4. Variation result in bending moment without and with infilled frame.

Particularly bending moment was observed more at bottom story for a model with infill walls. This is due to absence of infill walls or compression struts at the bottom story, as a result there is concentration for large amount of force subsequently from the upper stories leading to increased bending moment causing soft story collapse. Thus, soft storey's are to be avoided, if cannot be eliminated then adequate lateral strength is to be provided for the particular story. The possible schemes to reach these specified provisions is to introduce stiffer columns in the concerned storey, and provision of infill wall or shear walls at specified location at the soft story for the particular floor concerned in the building.

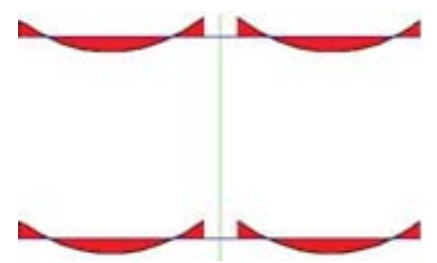

Before Column removal

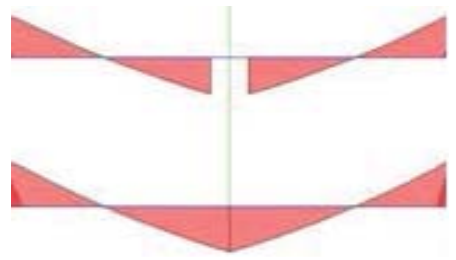

After Column removal

Figure 5. Bending moment before and after column removal. 
After removal of column, the axial force above removed column suddenly vanishes and is transferred-shared by the adjacent columns. Thus, the column above the removed column acts as floating column transferring point load on the beam which is again distributed to the adjacent columns through single beam element action in case of shorter and longer side central column removal while in case of corner column removal part of frame behaves like over hanged cantilever. The two bays above the removed column now acts as the one-single longer bay and is more sensitive to loss of beam and column above the removed column allowing for redistribution of internal forces. Hence in case of infilled frame structure the masonry-infill acts as the path barriers against shock wave propagation causing to less displacement of the beam and column above the removed column.
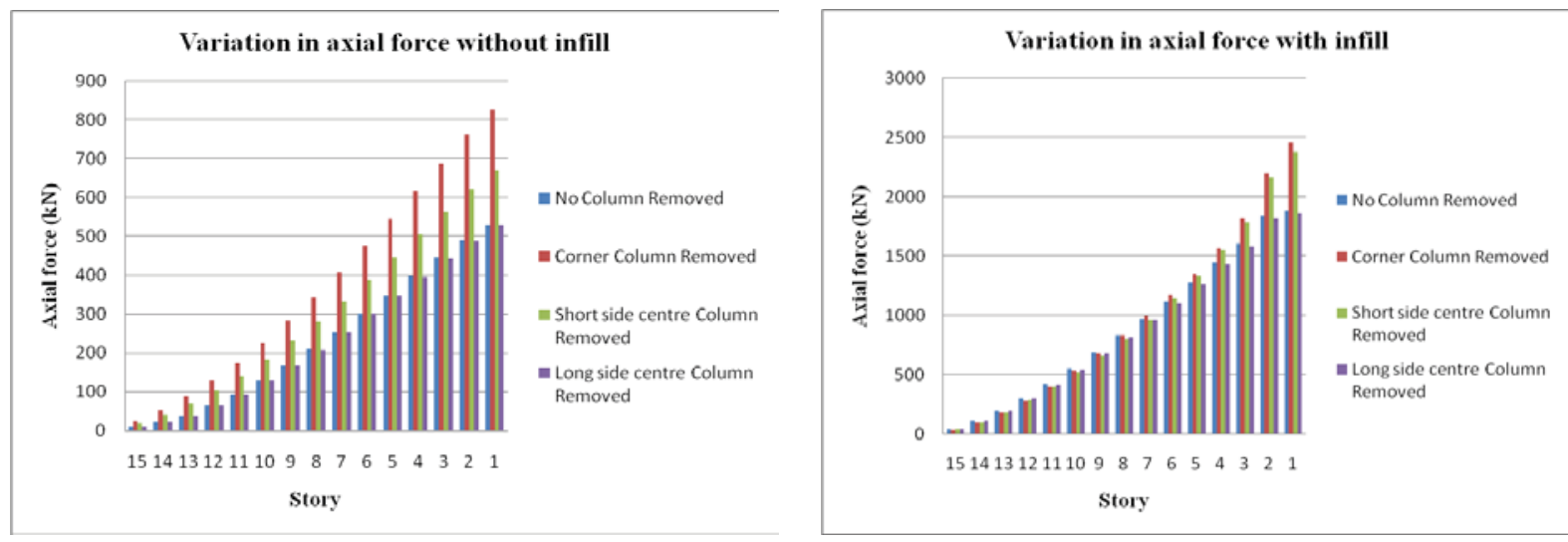

Figure 6. Variation result in axial force without and with infilled frame.

As in for axial force, a structure with infill walls had larger values as compared to a structure without infill walls. This is due to entanglement of stiffness factor from infill walls. As a result this leads to increased sectional size of the concerned columns. Regardless, infill walls increase lateral stiffness and minimize the P- $\chi$ effect. The presence of brick infill wall influences the overall behavior of the structure when subjected to lateral forces as well as for gravity loads, when these brick infills are taken into account they interact with the frames surrounding them. The lateral stiffness and lateral load carrying capability of structure is greatly influenced.

\section{B. Variation in shear force and displacement for three cases of column removed at base for a bare frame and a frame with masonry-infill structure. -}

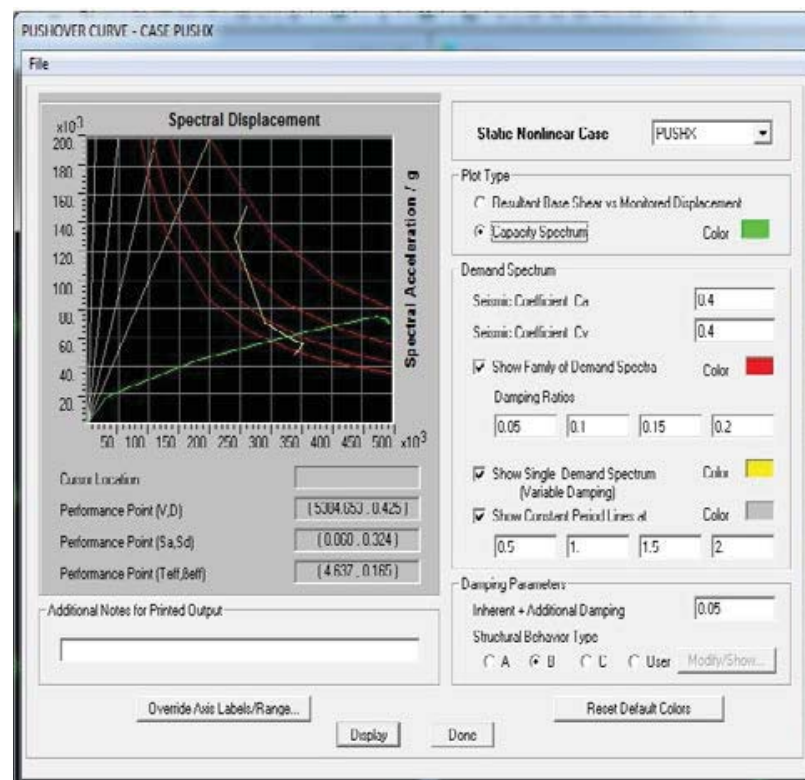

Without masonry-infill static pushover curve

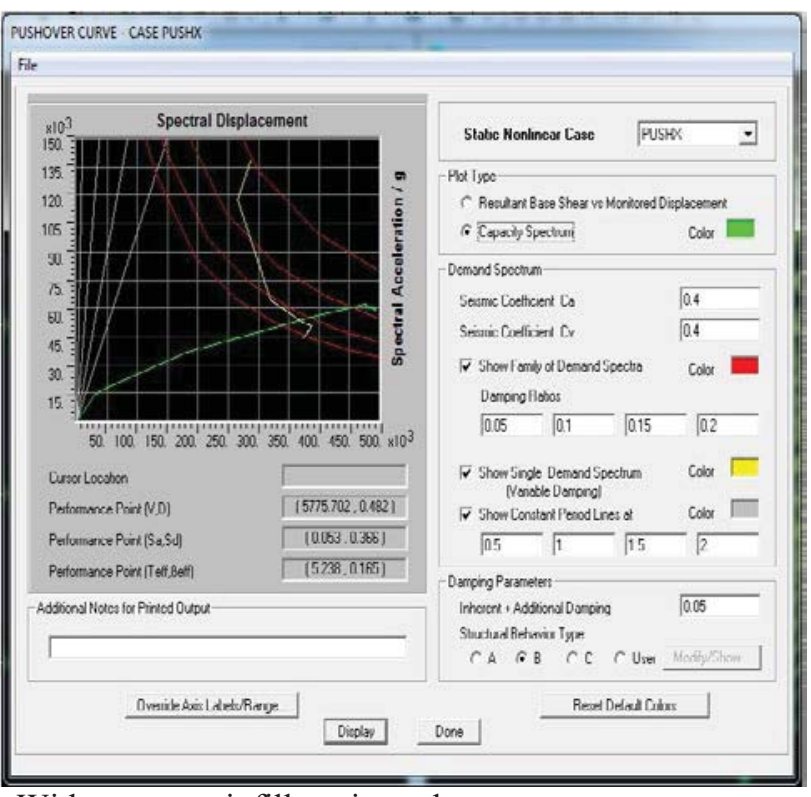

With masonry-infill static pushover curve

Figure 7. Variation result in static pushover curve- without and with infilled frame.

Irregularly designed infill can reduce natural period of the structure and increase the effectiveness of seismic force dominating towards overloading of parts for the structure. Designers frequently disregard those structural 
commitment about infill, the fundamental purposes may be that infill's have inherent properties, also it may be challenging to consider their effect genuinely. Due to the complications in design and methodology, for taking into account the effect of brick infill's in numerical analysis as those structural components will be not regular. The fundamental issue about analyzing the infill outline strengthened solid structures may be that, basically it is exceptionally troublesome to approximate truly, their inherent properties of infill in the plan technique. Calibration for brick units and mortar alone is insufficient for clarifying their inflexible cyclic behavior of brick infill's. Likewise codes about act, the individuals don't distinguish those impact from claiming infill panels, recommended that base shear be calculated based on the natural period of frame only. Besides being impracticable, such an approach can lead to high-risk design, because frame members receive unexpected shear forces and axial forces.

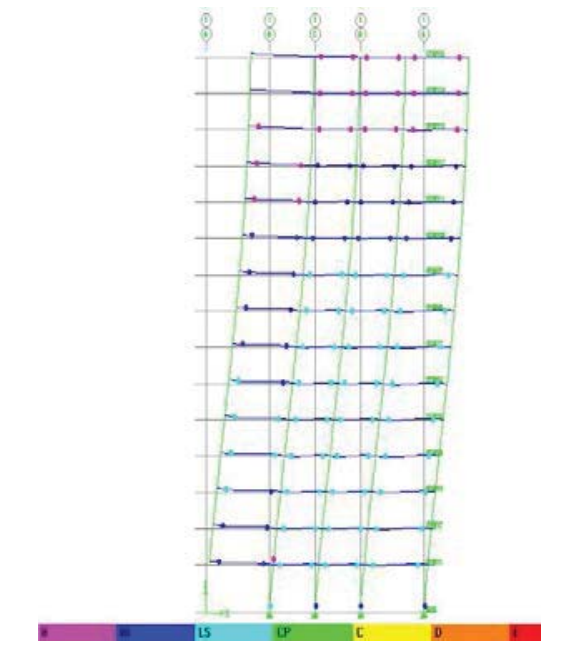

Without masonry-infill walls (Elevation1)

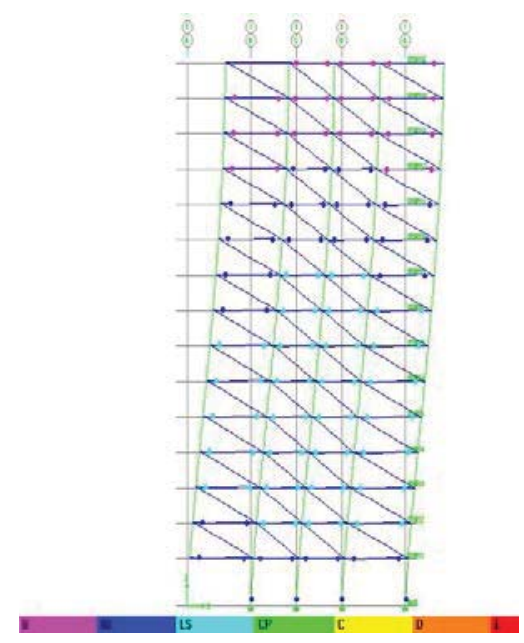

With masonry-infill walls (Elevation1)

Figure 8. Corner column removed at base (Hinge formations).

Overall damage is in continuous range between life safety and immediate occupancy level. Unsymmetrical placed infill may prompt torsion effects and imperfect masonry infill can alter the formation of ductile plastic hinges away from the advisable location at ends of beams to top of columns resulting in considerable increase in column shears. The frame -infill interaction may also cause local damage in frame element either near beam-column joints, or at mid height of columns. The combination of frames having low lateral stiffness with stiff but poor quality infill may lead to premature failure and subsequent collapse of infill.

Very light damage and limited cracking can be considered for a column adjacent to corner column for a model without infill wall. Whereas, for a column with infill walls flexural cracking in beams and columns may be considered. Under provisions for design earthquake there is, from moderate to light damage to the structure. In progressive collapse resistance, the infill wall may significantly change the collapse resistant potentials and damage patterns. Similarly, in progressive collapse space about research, investigation effects might make a great part unique in relation to the true behavior, if those infill walls are disregarded.

\section{IV.CONCLUSION}

1) These infill walls can decrease the displacement responses and increase the resistant capacity of progressive collapse, but may lead to increased demanding forces of members.

2) To discretize the structure designed for progressive collapse and earthquake resisting structure: Basically, for earthquake resistant structures the concept of strong- column and weak- beam mechanism is more effective, this is due to the fact that the progressive collapse resistant structures are based on vertical displacements and earthquake resistant structures are based on horizontal displacements. Thus a structure designed for progressive collapse resistance cannot sustain in high seismic regions, this is because progressive collapse resisting structures require more reinforcement in beams, while earthquake resisting structures require more reinforcement in columns.

3) Confirming to geometric irregularities the shorter side of structure gets more worse under various column loss scenarios. The reason is that, from longer bay heavy point load is shifted on shorter bay and the shorter bay tries to act like a cantilever. 
4) For regular buildings with continuous infilled frames, leads to increased stiffness and strength that may protect a building from damage associated with progressive collapse. But because of its greater stiffness and inadequate strength, infill panels may attract significantly greater forces that may lead to premature failure of infill, and possibly of the whole structure leading to disproportionate collapse. Therefore, it is reasonably conservative to consider the weight of brick infill only, rather than considering the stiffness of brick infill during the analysis of reinforced concrete frame structure.

\section{REFERENCES}

[1] Federal Emergency Management Agency, FEMA- 356: Prestandard and Commentary for the Seismic Rehabilitation of Buildings. 2000: Washington DC..

[2] American Society of Civil Engineers, ASCE- 41: Seismic Rehabilitation of Existing Buildings. 2006: Virginia.

[3] Applied Technology Council, ATC- 40: Seismic Evaluation and Retrofit of Concrete Buildings. 1996: California.

[4] American Concrete Institute, ACI 318- 14: Building Code Requirements for Structural Concrete. (Chapter. 21).

[5] Federal Emergency Management Agency, FEMA 440: Improvement of nonlinear staic seismic analysis procedures. June 2005: Washington

[6] IS: 1893-2002, "Indian Standard Criteria for Earthquake Resistant design of Structures Part 1-General provisions and buildings,(Fifth Revision)", Bureau of Indian standards, New Delhi, June 2002.

[7] IS: 456-2000, “Code of practice for Plain and Reinforced Concrete”, Bureau of Indian standards, New Delhi, November 2000.

[8] IS: 875 (Part 1. Dead Loads- Unit Weights of Building Materials and Stored Materials and Part 2. Imposed Loads)- 1987 (Second Revision) "Indian Standard Code of Practice For Design Loads (other than earthquake) for buildings and structures".

[9] General Service Administration (GSA), Alternate Path Analysis and Design Guidelines for Progressive Collapse Resistance, General Service Administration, United States, October 24, 2014.

[10] ETABS, User Interface Reference Manual. 2002, Computers and Structures (CSi): California.

[11] Dr. Vinod Hosur, "Earthquake- Resistant Design of Building Structures".

[12] Kwangho Kwon, Seromi Park and Jinkoo Kim, "Evaluation of Progressive Collapse Resisting Capacity of Tall Buildings", International Journal of High-Rise Buildings September 2012, Vol. 1.

[13] M Lupoae, C Baciu, D Constantin, H Puscau, "Aspects Concerning Progressive Collapse of a Reinforced Concrete Frame Structure with Infill Walls", Proceedings of the World Congress on Engineering 2011 Vol. III WCE 2011, July 6-8, 2011, London, U.K.

[14] Shuang Li, Shengping Liu, Changhai Zhai and Lili Xie, "Unified Analysis on Progressive and Seismic Collapses of RC frame Structure: The Effect of Masonry- infill walls" 15th World Conference on Earthquake Engineering 2012.

[15] Meng- Hao Tsai and Tsuei- Chiang Huang "Effect of Interior Brick- infill Partitions on the Progressive Collapse Potential of a RC Building: Linear Static Analysis Results" World Academy of Science, Engineering and Technology.

[16] D. G. Lu, S. S. Cui, P. Y. Song and Z. H. Chen "Robustness Assessment for Progressive Collapse of Framed Structures using Pushdown Analysis Method" 4th International Workshop on Reliable Engineering Computing (REC 2010).

[17] Meng- Hao Tsai and Tsuei- Chiang Huang "Numerical Investigation on Progressive Collapse Resistance of an RC Building with Brick Infills under Column Loss" International Journal of Civil, Environmental, Structural, Construction and Architectural Engineering Vol: 5, No: 10, 2011.

[18] R. Bento, S. Falao, F. Rodrigues "Non- Linear Static Procedures in Performance Based Seismic Design" 13th World Conference on Earthquake Engineering, Vancouver, B.C. Canada, August 1-6, 2004.

[19] Meng- Hao Tsai and Tsuei- Chiang Huang "Progressive Collapse Analysis of an RC Building with Exterior Non- Structural walls" The Twelfth Asia- Pacific Conference on Structural Engineering and Construction. 